\title{
Noncoding RNA Profiles in Tobacco- and Alcohol-Associated Diseases
}

\author{
Nayra Soares do Amaral ${ }^{1}$, Natalia Cruz e Melo ${ }^{2}$, Beatriz de Melo Maia ${ }^{1}$ \\ and Rafael Malagoli Rocha ${ }^{2, *}$ \\ 1 Molecular Morphology Laboratory, AC Camargo Cancer Center, São Paulo 01508-010, Brazil; \\ namaral@cipe.accamargo.org.br (N.S.d.A.); beatriz.melomaia@gmail.com (B.d.M.M.) \\ 2 Molecular Gynecology Laboratory, Gynecologic Department, Federal University of São Paulo, \\ São Paulo 04039-032, Brazil; natallimel@hotmail.com \\ * Correspondence: rafael.malagoli@phdlaboratorio.com.br; Tel.: +55-11-94024-4405 \\ Academic Editors: George A. Calin and Muller Fabbri \\ Received: 15 September 2016; Accepted: 14 December 2016; Published: 23 December 2016
}

\begin{abstract}
Tobacco and alcohol are the leading environmental risk factors in the development of human diseases, such as cancer, cardiovascular disease, and liver injury. Despite the copious amount of research on this topic, by 2030, 8.3 million deaths are projected to occur worldwide due to tobacco use. The expression of noncoding RNAs, primarily microRNAs (miRNAs) and long noncoding RNAs (lncRNAs), is modulated by tobacco and alcohol consumption. Drinking alcohol and smoking cigarettes can modulate the expression of miRNAs and lncRNAs through various signaling pathways, such as apoptosis, angiogenesis, and inflammatory pathways-primarily interleukin 6 (IL-6)/signal transducer and activator of transcription 3 (STAT3), which seems to play a major role in the development of diseases associated with these risk factors. Since they may be predictive and prognostic biomarkers, they can be used both as predictors of the response to therapy and as a targeted therapy. Further, circulating miRNAs might be valuable noninvasive tools that can be used to examine diseases that are related to the use of tobacco and alcohol. This review discusses the function of noncoding RNAs in cancer and other human tobacco- and alcohol-associated diseases.
\end{abstract}

Keywords: noncoding RNAs; microRNAs; long noncoding RNAs; tobacco; alcohol; cancer; chronic obstructive pulmonary disease; cardiovascular diseases

\section{Introduction}

Tobacco consumption and alcohol abuse are the most prevalent environmental risk factors for the development of diseases worldwide. According to the Global Information System on Alcohol and Health (GISAH), harmful alcohol use is a significant element in over 60 types of diseases and results in the deaths of 3.3 million persons annually [1]. The main diseases that are associated with alcohol abuse are cancers and cardiovascular diseases [2].

Tobacco use is the cause of mortality for approximately 6 million persons each year [1]. Although several tobacco consumption control programs have been initiated globally, the decline in the prevalence of smoking in the US has been less pronounced than in previous decades [3]. According to projections, 8.3 million deaths are expected to be associated with tobacco use worldwide in 2030-one-third of which will be caused by cancers, followed by cardiovascular disease and chronic respiratory diseases [4].

Despite the well-established knowledge on alcohol and tobacco abuse as risk factors for various diseases, their rates of consumption in many countries remain high [5], necessitating a greater understanding of the mechanisms in diseases that are linked to tobacco and alcohol abuse. Environmental factors can influence epigenetic events, such as DNA methylation, histone 
modifications, and the expression of noncoding RNAs (ncRNAs) [6,7]. Notably, several studies have demonstrated the function of noncoding RNAs in disease development with regard to smoking and alcohol use [8,9]. These molecules have been shown to be new biomarkers in human diseases, because they can leave specific signatures in biofluids and may contain information about the aggressiveness and response to therapy [10-13].

Based on the impact of the consumption of alcohol and tobacco on human health, the purpose of this review is to integrate the principal findings on this topic from the past 5 years to increase our understanding of the function of noncoding RNAs involved primarily in cancer and in other human diseases associated with tobacco use and alcoholism and highlight their importance as a new diagnostic and therapeutic approach.

\section{Noncoding RNAs}

For many years, it was believed that the genetic information in DNA was transcribed into RNA and subsequently translated into protein (the central dogma of biology). However, noncoding RNAs that can regulate target genes at the posttranscriptional level have been extensively studied [14]. ncRNAs are RNA transcripts that do not encode for a protein and are classified by size as small ncRNAs (sncRNAs), which are shorter than $200 \mathrm{bp}$, and long ncRNAs (lncRNAs) - those that are longer than $200 \mathrm{bp}$ [15]. microRNAs (miRNAs), which are $\approx 22$ nucleotides (nt) in length, are the most well-studied ncRNAs and have been linked to the consumption of tobacco and alcohol with regard to the development of tumors and other diseases.

\section{1. $m i R N A s$}

It is estimated that more than $60 \%$ of the mammalian genome is regulated by microRNAs [16]. A single miRNA is able to simultaneously regulate hundreds of mRNA sequences, highlighting the vast regulatory potential of these molecules. At the same time, a single mRNA can be regulated by several miRNAs [17].

miRNAs are known to regulate gene expression by binding to the $3^{\prime}$-untranslated region (3'-UTR) of messenger RNAs (mRNAs), to promoter regions [18], proteins [19], DNA [20] and Toll-like receptors (TLR) [21]. Direct regulation of the epigenetic machinery [22] has also been extensively demonstrated. miRNAs are not only able to downregulate, but also upregulate the expression of target genes [23].

A total of 1881 precursors and 2588 mature human miRNA sequences have been described [24]. miRNAs are involved in signaling pathways during the development of some diseases, primarily cancer $[25,26]$.

The expression of mature miRNAs is mediated by several enzymatic complexes that regulate their biogenesis. The first step of miRNA biogenesis (the canonical pathway) is the transcription of a miRNA gene by RNA polymerase II or RNA polymerase III into primary transcripts (pri-miRNA) that contain a stem loop structure $[27,28]$. Next, two enzymes, DROSHA and DiGeorge critical region 8 (DGCR8), recognize the pri-miRNA stem loop, which is cropped into a precursor miRNA (pre-miRNA). Pre-miRNAs have approximately 70 nucleotides and are transported from the nucleus to the cytoplasm by exportin-5 (XPO5) and are later processed into mature miRNAs (21 nt) [25]. In the cytoplasm, pre-miRNA* duplexes are processed by Dicer and other proteins, such as TAR RNA-binding protein (TRBP) and kinase R-activating protein (PACT). The miRNA duplex comprises two strands, one that is stabilized by Argonaute (AGO) protein and subsequently incorporated into an RNA-induced silencing complex and another that is usually degraded. The mature miRNA is integrated into a miRNA-mediated silencing complex (miRISC) and suppresses the expression of target genes, which are degraded, destabilized, or translationally inhibited [29].

Several studies have shown that changes in miRNA biogenesis, methylation, polymorphisms, mutations in miRNAs, and altered microenvironments, such as in hypoxia, contribute to dysregulated expression of miRNAs and accelerate the development of diseases [30-33]. Tobacco and alcohol induce changes in genes that can be related to miRNA maturation after cell exposure to these risk factors; there 
has been a reduction in the levels of mature miRNA and the expression and activity of Dicer [31,34], one of the main enzymes involved in miRNA biogenesis.

\section{2. $\ln R N A s$}

lncRNAs are able to interact with DNA, RNAs, and proteins [35]. For a long time, lncRNAs were considered to be non-functional, but, currently, these molecules appear to be the main regulators of transcription and translation [36] and have many functions, such as activation and repression of transcription, RNA enhancer, scaffolding protein for chromatin remodeling complexes, regulation of splicing of RNA, and sequestration of miRNA [35]. LncRNAs are transcribed by RNA polymerase II, and have a $5^{\prime}$-cap and a $3^{\prime}$-poly-A tail that can also be alternatively spliced [37]. Compared to mRNAs, lncRNAs frequently reside in the nucleus, are more tissue-specific, and have poorer interspecies sequence conservation [38]. The expression of lncRNAs in many tissues is important for homeostatic processes, including differentiation, organogenesis [39], and the immune response [40].

However, the dysregulation of IncRNAs is associated with the development of neurodegenerative [41], cardiovascular [42], and metabolic diseases [43] and cancer [44], including diseases associated with risk factors, such as tobacco and alcohol [44,45]. In this context, lncRNAs can be the key to understanding the development of normal and pathological biological processes. In this review, we report studies involving lncRNAs in diseases related to the use of tobacco and alcohol and their application as biomarkers and therapeutic targets.

\section{Diseases and Smoking: An Introduction}

The first report on the consequences of tobacco consumption on health was published in 1950 by Doll and Hill [46], who identified an association between cigarettes and lung cancer. Since then, the vast research in this area has expanded the number of tobacco-related diseases $[47,48]$. Cigarettes have over 7000 harmful chemicals and carcinogens $[49,50]$ that are involved in developing several types of tumors and respiratory and cardiovascular diseases [49,51-53].

\section{1. miRNAs in Tobacco-Associated Diseases}

\subsubsection{Lung Cancer}

Lung cancer is a major disease that is associated with tobacco use; this risk factor is responsible for $75 \%$ of all such cases of this disease. Lung cancer is usually diagnosed in the late stages [54,55], and its early detection in smokers can significantly reduce mortality rates [54]. miRNAs are notable targets for this approach and have been exploited in lung cancer. Techniques for analyzing miRNA expression on a large scale have increased our knowledge of the profiles of these molecules in smokers with and without cancer $[8,11,56-58]$ and in patients with cancer who have never smoked [59-62].

The combination of computerized tomography (CT) and the evaluation of miRNA expression reduces false-positive rates and increases the accuracy of early diagnosis in lung cancer [63-65]. The upregulation of miR-21 and miR-210 and the downregulation of miR-486-5p correlate with the use of tobacco and with the size of pulmonary nodules. In addition, the alteration of these miRNAs distinguishes patients with malignant pulmonary nodules from those with benign nodules with a sensitivity of $75.00 \%$ and a specificity of $84.95 \%$ [63].

The analysis of circulating miRNAs in body fluids, such as blood and sputum, is advantageous, because it is a minimally invasive technique that has been exploited in the early diagnosis of lung cancer in smoking $[12,13,58,64]$. The expression of miRNAs in sputum $[64]$ and serum $[12,13,58]$ refines the diagnosis in smokers with lung cancer compared with nonsmokers with good predictive value. In sputum samples, miR-31 and miR-210 are upregulated. In serum samples, miR-20a, miR-223, miR-21, and miR-145 [12,13] are upregulated and let-7i-3p and miR-154-5p are downregulated, suggesting that these miRNAs are potential biomarkers for early detection of lung cancer in smokers [58]. 
In addition, immune system components have been examined with regard to miRNAs. The expression of miR-19b-3p and miR-29b-3p in peripheral blood mononucleated cells (PBMCs) is related to the diagnosis of different stages of lung cancer [8].

The oral brush is another minimally invasive tool that detects differentially expressed miRNAs and can be a new clinical method for early diagnosis of lung cancer and for initial screening in smokers. The expression of miR-23a, miR-181c, miR-192, miR-194, miR-208, miR-337-5p, miR-338-3p, miR-502-5p, miR-542-3p, miR-628-5p, and miR-672 is upregulated in the oral mucosa of heavy smokers with lung cancer versus patients without cancer and light smokers [66].

miRNAs also have value in the treatment of smoking-related lung cancer $[67,68]$. miR-4423 is significantly downregulated in tumors of smokers and nonsmokers compared with normal tissue. Therapy with miR-4423 downregulates genes in the phosphatidylinositol 3-kinase (PIK3CA) and $\mathrm{SH} 2$-containg protein (SHC1) signaling pathways, which are fundamental for carcinogenesis, highlighting its tumor suppressive activity and its potential as a therapeutic target [67]. Furthermore, miRNAs have a role in the course of therapy; patients with lung cancer who have undergone surgical treatment show an increase in miR-625 and miR-361-3p, with similar expression levels as those in individuals with benign diseases and healthy persons, emphasizing that these miRNAs might have a protective influence on the development of lung cancer [54].

Further, Balansky et al. (2014) [68] determined the effects of lapatinib, a dual tyrosine kinase inhibitor largely used for breast cancer and other solid tumors, on miRNA expression by microarray in mice. Animals that were exposed to mainstream cigarette smoke (MSC) without lapatinib experienced global downregulation of miRNAs compared with the group that was administered the drug. Among the miRNAs that were downregulated by MSC were miR-92, miR-223, miR-27a, miR-139, miR-181c, miR-181, miR-27a, miR-322, miR-489, miR-511, miR-27a, miR-34b, miR-885, miR-19b, miR-19b, miR-20a, miR-292, miR-322, miR-362, miR-19b, miR-216a, miR-326, miR-341, miR-702, miR-19b, and miR-292, which are involved in the regulation of several genes-for example, Dicer, a key molecule in miRNA biogenesis [68]. Notably, the modulation of miRNAs is dependent on the level of tobacco consumption and can influence the prognosis of patients with lung cancer [11].

\subsubsection{Other Cancers}

The modulation of miRNAs in response to smoking has also been reported in stomach, esophagus, and oral tumors [69-71]. Smokers with gastric cancer experience an upregulation of miR-21 and downregulation of miR-143 in comparison with healthy subjects [70].

$\mathrm{X}_{\mathrm{i}}$ and colleagues (2015) [69] elegantly demonstrated that miR-217 is downregulated and that its target gene, kallikrein 7 (KLK7), increases in esophageal adenocarcinoma cell lines and esophageal tumors that have been exposed to cigarette smoke condensate (CSC). Further, the suppression of miRNA in the cell model and esophageal tumor samples correlated with hypermethylation of CpG islands in the coding region of miR-217. Notably, the reduction in miR-217 expression and the upregulation of KLK7 effected greater methylation levels in patients with a history of smoking compared which those who had never smoked [69].

In oral cancer, the expression profile of miRNAs in brush cytology of smokers is more heterogeneous than in nonsmokers with this tumor and healthy individuals. miR-10b-5p, miR-196a-5p, and miR-31-5p are upregulated in tumor tissues regardless of smoking habit, whereas miR-637 is upregulated exclusively in smokers, which may refine the diagnosis for this risk group [71].

\subsubsection{Chronic Obstructive Pulmonary Disease}

Chronic obstructive pulmonary disease (COPD) is characterized by progressive inflammation of the airways, the chief cause of which is cigarette smoking [72]. The heterogeneity of COPD is one of the reasons for the difficulty in developing effective therapies for it [73], prompting many studies to determine the molecular mechanisms of the disease to identify therapeutic targets. The expression of genes such as transforming growth factor- $\beta$ (TGF- $\beta$ ) and tripeptide Gly-His-Lys (GHK), is associated 
with increased severity of regional emphysema in individual lungs, and these genes mediate several pathways, such as inflammation, extracellular matrix remodeling, and tissue repair [74].

Smoking can potentiate the inflammatory process in COPD, altering the expression of miRNAs and these molecules can support in the diagnosis, because they are differentially expressed between groups of normal individuals compared to groups of smokers with COPD [75,76]. miRNAs interfere with the expression of genes that are involved in progressive inflammation of the airways and lungs-let-7c and miR-125b are lower in currently smoking patients with COPD compared with healthy subjects; however, these miRNAs are not differentially altered between ex-smokers and healthy controls. A decrease in let-7c is associated with increased levels of tumor necrosis factor receptor II (TNFR-II). The authors suggest that these miRNAs are associated in the development of COPD during exposure to cigarettes but not in the inflammation of airways during smoking cessation [76]. Ezzie et al. (2012) [77] identified 70 miRNAs that were differentially expressed in lung tissue among smokers with COPD and healthy smokers. miR-223 and miR-1274a were upregulated in subjects with COPD versus smokers without obstruction, and miR-15b was increased in COPD patients compared with smokers without obstruction and was differentially expressed between disease severities. In vitro, exposure to cigarette smoke extract upregulates miR-7 and downregulates EPAC1_important genes in the pathogenesis of COPD, including inflammation [76].

In addition, tobacco can participate in the alteration of $\mathrm{T}$ cells, macrophages, neutrophils, and the expression of miRNAs that play a key role in the immune response [78]. miR-146b-3p, miR-150, and miR-210 are downregulated in alveolar macrophages of smokers compared with nonsmokers. Further, heavy smokers experience global repression of miRNA versus light smokers; three of these miRNAs are differentially expressed (miR-146b-3p, miR-150, and miR-210), as validated in a second set of alveolar macrophage samples [79]. Another study has shown that alveolar macrophages from chronic active cigarette smokers express fewer mature miRNA transcripts, in part due to sumoylation of Dicer [34]. In addition, miR-199a-5p is downregulated in regulatory T cells (Tregs) in patients with COPD versus healthy smokers. Also, miR-199a-5p modulates the response of Tregs through the TGF- $\beta$ pathway [78].

Further, normal lung fibroblasts that are exposed to cigarette have lower RelB levels when miR-146a is upregulated; this upregulation is significant in COPD lung tissue compared with normal lung [80]. Notably, miR-146a is a potential therapeutic target for COPD, and the rs2910164 polymorphism in it is associated with a decrease in miR-146a levels and a rise in cyclooxygenase 2 (COX2) in smokers with COPD [81].

Circulating miRNAs have also been examined as a clinical tool for COPD patients [53,81-83]. Shi and colleagues (2015) [83] first identified 11 differentially expressed miRNAs in lung tissues from smokers with COPD, non-COPD smokers, and healthy nonsmoking controls. Five of these miRNAs (miR-181a, miR-203, miR-338, miR-1, and miR-199a) were evaluated in the blood of the three groups, and miR-203 levels were higher in the blood of smokers and COPD patients compared with nonsmoking controls. It has been suggested that miR-203 contributes to the development of COPD through the repression of nuclear factor $\kappa$-light-chain-enhancer of activated B cells (NF- $\mathrm{kB}$ ) signaling by targeting TAK1 and PI3KCA and that this miRNA can be used as a new biomarker for COPD diagnosis. Plasma levels of miR-106b decreased progressively after COPD patients stopped smoking, suggesting that this miRNA is an important clinical marker in plasma that is indicative of COPD [82]. Further, in the plasma of patients with COPD, miR-4455 and miR-4785 were differentially expressed between current smokers and never-smokers [81].

Thus, miRNAs govern vital inflammatory responses, regulating pro-inflammatory cytokines in patients with COPD, rendering them potentially valuable therapeutic and diagnostic tools [72].

\subsubsection{Cardiovascular Diseases}

Cardiovascular diseases are the leading cause of death in the world; more than 17 million people die each year of cardiovascular diseases, for which cigarette use is one of the main risk factors [84]. 
Little is known about the changes of miRNAs in the development of these diseases after exposure to smoke or alcohol consumption, but in vitro findings and clinical observations have confirmed that the use of cigarettes spurs the development of cardiovascular diseases [51,52]. Exposure of cardiomyocytes to nicotine induces fibrosis; reduces cell viability and miR-133 levels; and increases membrane potential, DNA degradation, and the expression of caspase 9, a target of miR-133 [51]. In abdominal aortic aneurysms, miR-21 is upregulated in response to nicotine and pathological progression. miR-21 is a notable therapeutic target for cardiovascular disease, because its inhibition in mice inhibits cell proliferation and increases apoptosis in the aortic wall, protecting against expansion of the aneurysm and the effects of nicotine [52].

\section{Alcohol Abuse and Alcohol-Related Diseases}

Excessive alcohol consumption is an important health problem, because it causes over 200 diseases, such as cancer, obesity, and liver and cardiovascular diseases [1,2]. Alcohol abuse is responsible for a significant percentage of mortality from these diseases [1]. Although alcohol and acetaldehyde have relatively low carcinogenicity, the alcohol content is high in alcoholic beverages [85], making alcohol abuse a major risk factor for the development of liver tumors, cancers of the head and neck, and breast tumors [2].

\section{1. miRNAs in Alcohol-Associated Diseases}

\subsubsection{Liver Cancer}

Liver cancer is one of the most common malignant tumors globally and has the third highest mortality rate, with approximately 700,000 new cases annually worldwide [86]. The main risk factors for hepatocellular cancer (HCC) include alcohol consumption, the presence of cirrhosis, hepatitis B/hepatitis C virus (HBV/HCV) infection, nonalcoholic steatosis, and hepatitis [87-89]. Liver cancer generally has a late diagnosis and poor prognosis and is resistant to therapy [90].

Several studies have shown that ethanol modulates microRNA expression in the liver [91-94], but little is known about the relationship between alcohol consumption and miRNA expression in the development of liver cancer. Nevertheless, alcohol alters the levels of miRNAs that regulate important cellular processes in hepatic tumorigenesis [9,30,91].

Meng and colleagues (2012) [30] reported that the positive regulation of miR-34a after treatment of liver cancer and normal cell lines with alcohol is associated with the hypomethylation of the promoter region of this miRNA. By microarray analysis, miR-34a was differentially expressed in the hepatic tissue of rats after administration of ethanol compared with rats in the control group. In addition, miR-34a has significant function in modulating genes that mediate hepatic fibrosis during cell remodeling, with caspase 2 and sirtuin 1 (SIRT1) as direct targets and matrix metalloproteases 1 and 2 (MMP1 and MMP2) as indirect targets [30]. In alcoholic liver tissue, the expression of miR-200 is impaired, and its target, $S P R R 2 a$, is upregulated. In vitro, transfection of $S P R R 2 a$ into cholangiocarcinoma cells downregulates miR-200 and increases mesenchymal-epithelial transition (MET) genes, such as DESMOPLAKIN, E-CADHERIN, CLAUDIN-7, LAMININ SUBUNIT BETA-3, MUCIN-1, and ZEB1 [91]. Francis et al. (2014) [9] observed that normal liver and liver cancer cells that have been treated with ethanol upregulate miR-21 - to a greater extent in the latter. In addition, cells that have been transfected with miR-21 showed greater transformation and survival.

The consumption of alcohol might be associated with mechanisms that regulate the expression of miRNAs in liver cancer, such as the modulation of genes that participate in the biogenesis of miRNAs and polymorphisms in miRNA-coding regions [31,32,95]. The expression of seven genes (DGCR8, P68, P72, DICER, AGO3, AGO4, and PIWIL4) that mediate the biogenesis of miRNAs declined in liver cancer samples, especially in nonviral tumors, compared with normal liver. Downregulation of these genes correlated with a worse prognosis and the presence of risk factors, such as smoking and alcohol 
consumption. Also, the promoter regions of P72, AGO4, and DGCR8 were methylated in HCC cell lines [31].

Single-nucleotide polymorphisms in miRNAs can alter their expression and their binding to target mRNA sequences; thus, this mechanism might increase one's susceptibility to tumors [32]. Individuals who have the CT or CC rs3746444 polymorphism in miR-499 might have significantly greater susceptibility to liver cancer. The combined effects of polymorphisms and environmental risk factors, such as smoking and alcohol consumption, have been reported [32].

These data demonstrate that the involvement of alcohol in miRNA modulation in hepatic tumors should be studied further. It is important to increase our knowledge about liver cancer with regard to an early diagnosis and therapeutic resistance.

\subsubsection{Other Cancers}

Alcohol is a risk factor for head and neck tumors (HNSC), and as shown by RNAseq analysis of these tumors, individuals who consume alcohol have disparate miRNA profiles and lower survival rates compared with those who do not. miR-30a-5p, miR-934, miR-3164, and miR-3178 are upregulated in oral tumors from those who consume alcohol, in oral epithelial tumor cell lines, and normal cells on exposure to acetaldehyde. Cells that are transfected with miR-30a-5p and miR-934 upregulate $B C L 2$, which mediates processes such as proliferation and invasion. Notably, cells in which these miRNAs have been knocked down become sensitive to cisplatin and show less proliferation and invasiveness [96].

In oral cancer, miR-34a, miR-99A, miR-143, and miR-380-5p are negatively regulated in patients with cancer compared with healthy subjects. Further, increased expression of miR-34a is associated with alcohol consumption and histological grade, this miRNA had targeted MDM4, a negative regulator of TP53, suggesting an indirect mechanism of suppression of p53 in oral cancer [97]. In premalignant lesions of the larynx, miR-10a levels are reduced and miR-34c increases gradually by severity of the dysplasia, wherein miR-34c expression levels are higher in patients who consume alcohol [98].

In samples of gastric cancer, there is differential expression of miRNAs in association with alcohol consumption. For example, miR-203, miR-205, and miR-223 are upregulated in patients with gastric cancer who consume alcohol regularly [70].

\subsubsection{Other Alcoholic Liver Diseases}

Alcoholic liver disease (ALD) is a spectrum of diseases-including steatosis, hepatitis, and alcoholic cirrhosis-that can progress to hepatocellular carcinoma [99].

An analysis of genes and miRNAs was performed in 4 groups: healthy non-drinkers, healthy drinkers without liver disease, and drinkers with hepatitis or cirrhosis. The results revealed that six miRNAs (miR-570, miR-122, miR-34b, miR-29c, miR-922, and miR-185) were able to downregulate 79 target genes involved in various processes, such as the immune response, inflammation, and glutathione metabolism [100].

miRNAs that are associated with extracellular vesicles (EVs) and exosomes can be used as biomarkers in alcoholic hepatitis $[93,101,102]$. The number of circulating EVs increases, depending on the dose and length of alcohol exposure in mice. A microarray analysis of exosomes in alcohol-treated mice versus controls showed that miR-192, miR-122, and miR-30a differentiate alcohol-induced liver injury in mice and humans with excellent diagnostic accuracy [102]. Exosomes mediate the communication between alcohol-treated hepatocytes and immune cells, and the levels of miR-27a in exosomes and inflammatory cytokines, such as interleukin 10 (IL-10) and TGF- $\beta$, are higher in alcohol-treated mice and patients with alcoholic hepatitis [101].

miRNAs are considered new targets for the diagnosis of and therapeutic interventions for alcoholic fatty liver (AFL) [30,103]. In mice with AFL, miR-199-3p, miR-214, miR-93, miR-146a, miR-191, and let-7b are downregulated and miR-129, miR-490, miR-21, miR-503, miR-183, and miR-185 are upregulated compared with healthy mice [103]. 
Alcoholic liver disease is characterized by the activation of a cascade of proinflammatory cytokines in the liver [104]. Bala et al. (2012) [93] demonstrated that circulating miR-122 and miR-155 are biomarkers of liver damage and modulators of proinflammatory cytokines in mice. Further, the upregulation of miR-217 and inflammatory cytokines in Kupffer cells of mice on administration of ethanol reduces SIRT1, and increases NF- KB expression. Thus, the inhibition of hepatic miR-217 is an interesting approach toward mitigating the inflammatory response in alcoholic steatosis [105].

In alcoholic and viral hepatitis, miR-122 functions in the regulation and replication of $\mathrm{HCV}$ and in the expression of host genes, including CYCLIN G1. In cells with and without HCV that have been exposed to acute concentrations of alcohol, miR-122 levels rise [92].

The intestinal barrier dysfunction is commonly associated with alcoholic liver disease. Experiments with monolayer cells and mice showed that exposure to alcohol increases miR-212 and hyperpermeability and downregulates zonula occludens-1 protein. Inhibition of miR-212 can reduce this effect; thus, this miRNA can be used as an interesting therapeutic intervention [106].

This review focused on altered miRNAs due to of the use of tobacco and alcohol in various human diseases. It has been shown in diverse studies that exposure to tobacco and alcohol alters the expression of several miRNAs in tumors (Table 1) and other diseases, such as cardiovascular, respiratory, and liver diseases (Table 2), in different samples, such as cells, animals, and humans. One of the main approaches among these studies was to quantify circulating miRNAs that are secreted from cells in body fluids, because they are stable molecules. Circulating microRNAs are advantageous, because they can be obtained through a minimally invasive technique, and they have been exploited to assist in the early diagnosis of lung cancer, COPD, and liver diseases [54,82,102,107] (Figure 1). The use of circulating miRNAs might facilitate the diagnosis of various diseases that are associated with tobacco consumption and alcohol abuse, focusing on the concept that different human diseases leave specific miRNA signatures in biofluids, which contain information about the aggressiveness and response to therapy.

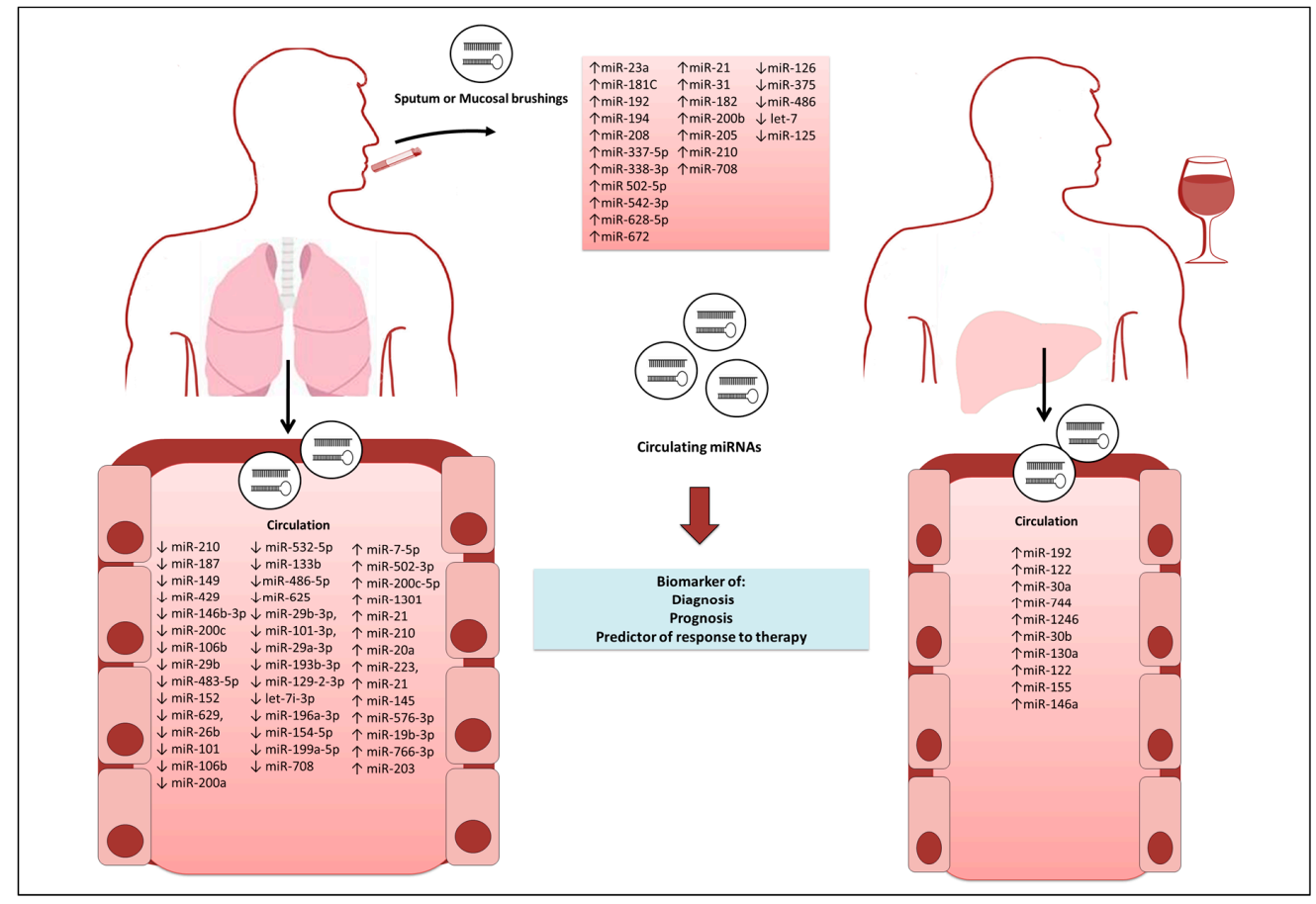

Figure 1. Circulating microRNAs (miRNAs) as early diagnostic biomarkers in tobacco- and alcohol-associated diseases. Circulating miRNAs from blood and sputum or mucosal brushings can be obtained through a minimally invasive technique and have been exploited to assist in the early diagnosis of several diseases. 
Table 1. List of microRNAs (miRNAs) altered by tobacco and alcohol exposition in distinct cancers.

\begin{tabular}{|c|c|c|c|c|c|}
\hline Cancer & miRNA & Regulation * & $\begin{array}{l}\text { Associated } \\
\text { Risk Factor }\end{array}$ & Samples & Ref. $\#$ \\
\hline Lung & miR-486-5p & $\downarrow$ & Tobacco & Plasma & [63] \\
\hline Lung & miR-625 & $\downarrow$ & Tobacco & Serum and cell lines & {$[54]$} \\
\hline Lung & miR-150 & $\downarrow$ & Tobacco & Tumor tissues & [108] \\
\hline Lung & miR-142-3p, miR-34c & $\downarrow$ & Tobacco & Tumor tissues & [109] \\
\hline Lung & $\begin{array}{l}\text { miR-126, miR-375 } \\
\text { miR-486 }\end{array}$ & $\downarrow$ & Tobacco & Sputum & {$[64]$} \\
\hline Lung & miR-322, miR-326 & $\downarrow$ & Tobacco & Mice & {$[68]$} \\
\hline Lung & $\begin{array}{c}\text { miR-29b-3p, miR-101-3p } \\
\text { miR-29a-3p } \\
\text { miR-193b-3p }\end{array}$ & $\downarrow$ & Tobacco & Mononuclear cells & [8] \\
\hline Lung & $\begin{array}{c}\text { miR-129-2-3p, let-7i-3p } \\
\text { miR-196a-3p } \\
\text { miR-154-5p }\end{array}$ & $\downarrow$ & Tobacco & Serum & [58] \\
\hline Cholangio & miR-200 & $\downarrow$ & Alcohol & Tumor tissues & [91] \\
\hline Laryngeal ** & miR-34c-5p & $\downarrow$ & Alcohol & Tumor tissues & [98] \\
\hline Esophageal & miR-217 & $\downarrow$ & Tobacco & Tumors and cell lines & {$[60]$} \\
\hline Gastric & miR-143 & $\downarrow$ & Tobacco & Tumor tissues & {$[70]$} \\
\hline Lung & $\begin{array}{l}\text { miR-7-5p, miR-502-3p, } \\
\text { miR-200c-5p, miR-1301 }\end{array}$ & $\uparrow$ & Tobacco & Serum & [58] \\
\hline Lung & $\begin{array}{c}\text { miR-23a, miR-181c, } \\
\text { miR-192, miR-194, } \\
\text { miR-208, miR-337-5p, } \\
\text { miR-338-3p, miR-502-5p, } \\
\text { miR-542-3p, miR-628-5p, } \\
\text { miR-672 }\end{array}$ & $\uparrow$ & Tobacco & Mucosal brushings & {$[66]$} \\
\hline Lung & miR-21, miR-210 & $\uparrow$ & Tobacco & Plasma & [63] \\
\hline Lung & miR-100 & $\uparrow$ & Tobacco & Tumor tissues & [59] \\
\hline Lung & $\begin{array}{l}\text { miR-224, miR-375, } \\
\text { miR-452 }\end{array}$ & $\uparrow$ & Tobacco & Tumor tissues & [109] \\
\hline Lung & $\begin{array}{l}\text { miR-20a, miR-223, } \\
\text { miR-21, miR-145 }\end{array}$ & $\uparrow$ & Tobacco & Plasma & [12] \\
\hline Lung & $\begin{array}{c}\text { miR-21, miR-31, miR-182, } \\
\text { miR-200b, miR-205, } \\
\text { miR-210, miR-708 }\end{array}$ & $\uparrow$ & Tobacco & Sputum & {$[64]$} \\
\hline Lung & $\begin{array}{l}\text { miR-576-3p, miR-19b-3p } \\
\text { miR-766-3p }\end{array}$ & $\uparrow$ & Tobacco & Mononuclear cells & {$[8]$} \\
\hline Lung & miR-21 & $\uparrow$ & Tobacco & Serum and cell lines & [13] \\
\hline Gastric & miR-21 & $\uparrow$ & Tobacco & Brush cytology & [70] \\
\hline Oral & miR-637 & $\uparrow$ & Tobacco & Tumor tissues & [71] \\
\hline Liver & miR-34 & $\uparrow$ & Alcohol & Mice and cell lines & [30] \\
\hline Liver & $\mathrm{miR}-21$ & $\uparrow$ & Alcohol & Mice and cell lines & [9] \\
\hline Oral & miR-34 & $\uparrow$ & Alcohol & Tumor tissues & [97] \\
\hline $\begin{array}{l}\text { Head and } \\
\text { Neck }\end{array}$ & $\begin{array}{l}\text { miR-30a-5p, miR-934, } \\
\text { miR-3164, miR-3178 }\end{array}$ & $\uparrow$ & Alcohol & Tumor tissues & {$[96]$} \\
\hline Gastric & $\begin{array}{l}\text { miR-203, miR-205, } \\
\text { miR-223 }\end{array}$ & $\uparrow$ & Alcohol & Tumor tissues & [70] \\
\hline
\end{tabular}

Legends: * Regulation: Green arrows indicate miRNA downregulation; Red arrows indicate miRNA upregulation; ** Premalignant lesion; Ref. \#: References; All miRNAs reported in this table have been altered by exposure to alcohol or tobacco. 
Table 2. List of miRNAs altered by tobacco and alcohol exposure in other diseases.

\begin{tabular}{|c|c|c|c|c|c|}
\hline Disease & miRNA & Regulation * & $\begin{array}{l}\text { Associated } \\
\text { Risk Factor }\end{array}$ & Samples & Ref. " \\
\hline \multicolumn{6}{|c|}{ Cardiovascular Diseases } \\
\hline $\begin{array}{l}\text { Myocardial } \\
\text { Fibrosis }\end{array}$ & miR-133 & $\downarrow$ & Tobacco & Cell line & [51] \\
\hline $\begin{array}{l}\text { Abdominal } \\
\text { aortic } \\
\text { aneurysms }\end{array}$ & $\operatorname{miR}-21$ & $\uparrow$ & Tobacco & $\begin{array}{l}\text { Tissue, mice, } \\
\text { cell line }\end{array}$ & [52] \\
\hline $\begin{array}{l}\text { Intestinal } \\
\text { barrier } \\
\text { dysfunction }\end{array}$ & miR-212 & $\uparrow$ & Alcohol & $\begin{array}{l}\text { Mice and cell } \\
\text { line }\end{array}$ & [106] \\
\hline \multicolumn{6}{|c|}{ Respiratory diseases } \\
\hline COPD & miR-199a-5p & $\downarrow$ & Tobacco & $\begin{array}{l}\text { Mononuclear } \\
\text { cells }\end{array}$ & [78] \\
\hline COPD & $\begin{array}{l}\text { miR-146b-3p, miR-150, } \\
\text { miR-210 }\end{array}$ & $\downarrow$ & Tobacco & $\begin{array}{l}\text { Bronchoalveolar } \\
\text { lavage }\end{array}$ & [79] \\
\hline COPD & $\begin{array}{c}\text { miR-708, miR-200a, miR-210, } \\
\text { miR-187, miR-149, miR-429, } \\
\text { miR-146b-3p, miR-200c }\end{array}$ & $\downarrow$ & Tobacco & $\begin{array}{l}\text { Alveolar } \\
\text { macrophages }\end{array}$ & [34] \\
\hline COPD & let-7, miR-125 & $\downarrow$ & Tobacco & Sputum & [75] \\
\hline COPD & $\begin{array}{l}\text { miR-106b, miR-29b, } \\
\text { miR-483-5p, miR-152, miR-629, } \\
\text { miR 26b, miR-101, miR-106b, } \\
\text { miR-532-5p, miR-133b }\end{array}$ & $\downarrow$ & Tobacco & Plasma & [82] \\
\hline COPD & miR-7 & $\uparrow$ & Tobacco & Cell line & [76] \\
\hline COPD & miR-203 & $\uparrow$ & Tobacco & Blood & [83] \\
\hline COPD & miR-146a & $\uparrow$ & Tobacco & Cell line & [80] \\
\hline \multicolumn{6}{|c|}{ Liver diseases } \\
\hline $\begin{array}{l}\text { Alcoholic liver } \\
\text { diseases }\end{array}$ & $\begin{array}{l}\text { miR-199-3p, miR-214, miR-93, } \\
\text { miR-146a, miR-191, let-7b }\end{array}$ & $\downarrow$ & Alcohol & Tumor tissues & [103] \\
\hline Steatosis & miR-217 & $\uparrow$ & Alcohol & $\begin{array}{l}\text { Mice and cell } \\
\text { line }\end{array}$ & [105] \\
\hline $\begin{array}{l}\text { Alcoholic } \\
\text { hepatitis }\end{array}$ & miR-27a & $\uparrow$ & Alcohol & $\begin{array}{l}\text { Cell line and } \\
\text { plasma }\end{array}$ & {$[101]$} \\
\hline $\begin{array}{l}\text { Alcoholic } \\
\text { hepatitis }\end{array}$ & $\begin{array}{c}\text { miR-192, miR-122, miR-30A, } \\
\text { miR-744, miR-1246, miR-30, } \\
\text { miR-130a }\end{array}$ & $\uparrow$ & Alcohol & $\begin{array}{l}\text { Human plasma } \\
\text { and mice }\end{array}$ & [102] \\
\hline $\begin{array}{l}\text { Hepatitis C } \\
\text { Virus }\end{array}$ & miR-122 & $\uparrow$ & Alcohol & Cell line & [92] \\
\hline $\begin{array}{l}\text { Alcoholic liver } \\
\text { diseases }\end{array}$ & miR-122, miR-155, miR-146a & $\uparrow$ & Alcohol & $\begin{array}{l}\text { Plasma and } \\
\text { serum of mice }\end{array}$ & [93] \\
\hline $\begin{array}{l}\text { Alcoholic liver } \\
\text { diseases }\end{array}$ & $\begin{array}{l}\text { miR-570, miR-122, miR-34b, } \\
\text { miR-29c, miR-922, miR-185 }\end{array}$ & $\uparrow$ & Alcohol & Tumor tissues & [100] \\
\hline $\begin{array}{l}\text { Alcoholic liver } \\
\text { diseases }\end{array}$ & $\begin{array}{l}\text { miR-129, miR-490, miR-21, } \\
\text { miR-503, miR-183, miR-185 }\end{array}$ & $\uparrow$ & Alcohol & Tumor tissues & [103] \\
\hline
\end{tabular}

Legends: ${ }^{*}$ Regulation: Green arrows indicate miRNA downregulation; Red arrows indicate miRNA upregulation; COPD: Chronic obstructive pulmonary disease; Ref. \#: References; All miRNAs reported in this table have been altered by exposure to alcohol or tobacco.

\section{Long Noncoding RNAs in Tobacco and Alcohol-Associated Diseases}

lncRNAs are involved in tobacco and alcohol consumption-associated carcinogenesis $[110,111]$. Because the findings on lncRNAs and environmental risks are relatively new, we will focus on the function of these molecules in lung cancer and hepatocellular carcinoma-the areas in which there is more relevant information. 
Hepatic reduction in the expression of SIRT1 promotes steatosis, inflammation, and fibrosis in response to ethanol challenge in mice [112]. A highly conserved lncRNA, MALAT1 (metastasis-associated lung adenocarcinoma transcript 1 ), has been demonstrated to have a strong propensity to interact with SIRT1. MALAT1 increases in liver fibrosis and mediates the degradation or inactivation of SIRT1 through its association with the histone deacetylase SIRT1 [111]. In addition, the overexpression of IncRNA MALAT1 can predict the recurrence of hepatocellular carcinoma after liver transplantation [45].

The exposure of cells to cigarette smoke extract (CSE) induces the epithelial-mesenchymal transition (EMT) during transformation, and lncRNAs might be involved in inflammation through the EMT in human bronchial epithelial (HBE) cells. In CSE-treated HBE cells, interleukin 6 (IL-6) activates phospho-Signal transducer and activator of transcription 3 (STAT3) and increases the levels of lncRNA mRNA. CSE also upregulates HOX transcript antisense RNA (HOTAIR) and MALAT1. By chromatin immunoprecipitation (ChIP) assay, STAT3 interacts with the promoter regions of HOTAIR. Further, malignant transformation was reversed when cells were treated with HOTAIR small interfering RNA (siRNA) for $24 \mathrm{~h}$ [7]. Similarly, MALAT1 participates in the CSE-induced EMT in HBE cells and is regulated by miR-217. MALAT1 has been implicated in the EMT through the enhancer of zeste homolog 2 (EZH2) pathway. Downregulation of miR-217 increases MALAT1 levels to induce EZH2/histone H3 lysine 27 trimethylation (H3K27ME3), and this pathway modifies the EMT and causes malignant transformation in HBE cells [110].

Recently, lncRNA polymorphisms have been studied. rs2839698 in the lncRNA H19 is associated with a lower response to platinum-based chemotherapy, primarily in nonsmoking females with adenocarcinoma, and rs1899663 in HOTAIR correlates with the response to chemotherapy in male smokers in a dominant model [113].

The two most extensively studied lncRNAs in lung cancer with regard to tobacco use are HOTAIR and MALAT1. However, Thai et al. (2013) [44] have reported an association between smoking, lung cancer, and an lncRNA-1 (SCAL1) in vitro and in vivo. SCAL1 is more highly expressed in smokers compared with nonsmokers, and CSE induces its expression in vitro in airway epithelial cultures. Notably, SCAL1 is also upregulated in several lung cancer cell lines. SCAL1 is regulated by nuclear factor (erythroid-derived 2)-like 2 (NRF2)—a mechanism that might be involved in oxidative stress in airway epithelial cells [44].

Although many studies have examined the function of noncoding RNAs and environmental factors, our understanding of them remains insufficient [114]. Recent studies have evaluated the activity of lncRNAs in the development of diseases that are associated with tobacco and alcohol abuse, but little is known about the mechanisms behind this progression. However, the data that are being generated are providing insights into how lncRNAs are involved in diseases that are associated with environmental factors and how they can guide the development of new clinical tools.

\section{Noncoding RNAs Involved in Signaling Pathways}

According to the studies addressed in this review, the major miRNAs associated with tobacco and alcohol are miR-21, miR-34a, miR-34c [30,97,98,109], miR-223 [12,70], miR-375, and miR-210 [63,64], which are involved in many signaling pathways, such as proliferation [52], transformation $[9,13]$, inflammation [9,13], angiogenesis [13], apoptosis, and the cell cycle [12,30,70,71,98,109].

Tobacco and alcohol seem to regulate miR-34c and miR-223 through the signaling pathways of apoptosis and the cell cycle [12,30,70]. miR-34c is downregulated in laryngeal premalignant epithelial lesions [98] and lung cancer, associated with the use of tobacco [109], and upregulated in two studies related to alcohol consumption $[30,97]$. Exposure to alcohol through miR-34a reduces the expression of target pro-apoptotic genes (CASPASE 2, MDM4) and a microtubule regulator (SIRT1) and is involved with the remodeling of the extracellular matrix (MMP1 and MMP2) [30]. The upregulation of miR-223 has been reported in two studies in smoking patients with lung cancer [12] and in gastric cancer after exposure to alcohol [70]. The targets of miR-223 are a tumor suppressor, tumor protein p53-inducible nuclear protein 1 (TP53INP1), and a microtubule regulator, stathmin 1 (STMN1) [115,116]. Thus, 
miR-34a and miR-223 are interesting molecules to be studied in conditions associated with the use of tobacco and alcohol for the development of new tools for diagnosis and therapy.

According to our findings, the upregulation of miR-210 is a non-invasive biomarker in serum samples [63] and sputum [64]. The increased expression of miR-210 is also detected in a variety of other tumors and correlates with advanced breast and oral cancers $[117,118]$. In the literature, miR-210 is associated with tumorigenesis and hypoxia pathways $[119,120]$. miR-375 was found in two studies. Whereas Mascaux and colleagues (2013) [109] showed that miR-375 is upregulated in current smokers compared with former smokers, Shen and colleagues (2014) [64] reported that it is downregulated between smokers with and without lung cancer. Despite the interesting findings of the direct association of miR 210 and miR-375 with smoking and miR-223 with tobacco and alcohol use, the pathways involved between these miRNAs and the use of these risk factors have not been elucidated.

Of the miRNAs in tobacco- and alcohol-associated diseases that have been discussed in this review, miR-21 is the most frequently reported, having been described in eight studies-five on tobacco use and two on alcohol consumption. miR-21 regulates the expression of genes that mediate apoptosis, proliferation, invasion, and angiogenesis $[9,13,52,108]$. miR-21 is associated with tobacco use in lung tumors [12,58,63], gastric tumors [70] and abdominal aortic aneurysms [52]. In liver diseases, miR-21 has also been linked to alcohol consumption [9,103]. Thus, evaluating miR-21 expression can be helpful in diagnosing the early stages of lung cancer $[12,63]$. In gastric tumor samples, elevated miR-21 expression correlates with smoking and low social status [70].

Exposure to tobacco and alcohol modulates the expression of lncRNAs, such as MALAT 1 and HOTAIR, and miRNAs through the IL-6/STAT3 pathway (Figure 2). Liu et al. (2016) [13] and Francis et al. (2014) [9] showed that the regulation of miR-21 in lung and liver cancers is associated with the use of cigarettes and alcohol, respectively, by this pathway. IL-6 phosphorylates and activates STAT3, which in turn activates miR-21 $[9,13]$.

miR-21 is upregulated in the serum of smokers compared with nonsmokers and correlates with high tobacco consumption. In vitro, transformed HBE cells that have been chronically exposed to CSE express and secrete more miR-21 in exosomes and experience increased angiogenesis. In addition, STAT3 regulates miR-21 levels and the secretion of exosomes in transformed cells. Notably, the supernatant from transformed cells induces angiogenesis through vascular endothelial growth factor (VEGF) in cells that have not been exposed to CSE [13].

Normal human hepatocytes (N-Hep), human hepatic stellate cells (HSCs), and hepatocellular carcinoma cells (HepG2) that are treated with ethanol upregulate miR-21, mainly in tumor cells. Further, normal cells that have been transfected with miR-21 have an increased capacity to transform as well as to survive, downregulating their proapoptotic target genes, FASLG (TNF superfamily, member 6) and DR5 (death receptor 5). Liver tissue that has been exposed to ethanol expresses more phosphorylated STAT3 and miR-21. Silencing IL-6 in normal and hepatocarcinoma cells that have been exposed to ethanol significantly reduces miR-21 expression and phosphorylated STAT3 activity, as shown in animal models [9].

In abdominal aortic aneurysms, mice and cells that have been exposed to nicotine and smoking patients have high levels of miR-21, which correlates with a reduction in tumor suppressors, like PTEN and PDCD4; upregulation of inflammatory genes, such as CXCL1, CXCL12, Il6, and MCP1; and disease severity. In addition, cells that have been transfected with anti-miR-21 downregulate Ki-67, a proliferation marker, and express high levels of proapoptotic genes, such as caspase 3 and PTEN [52]. 


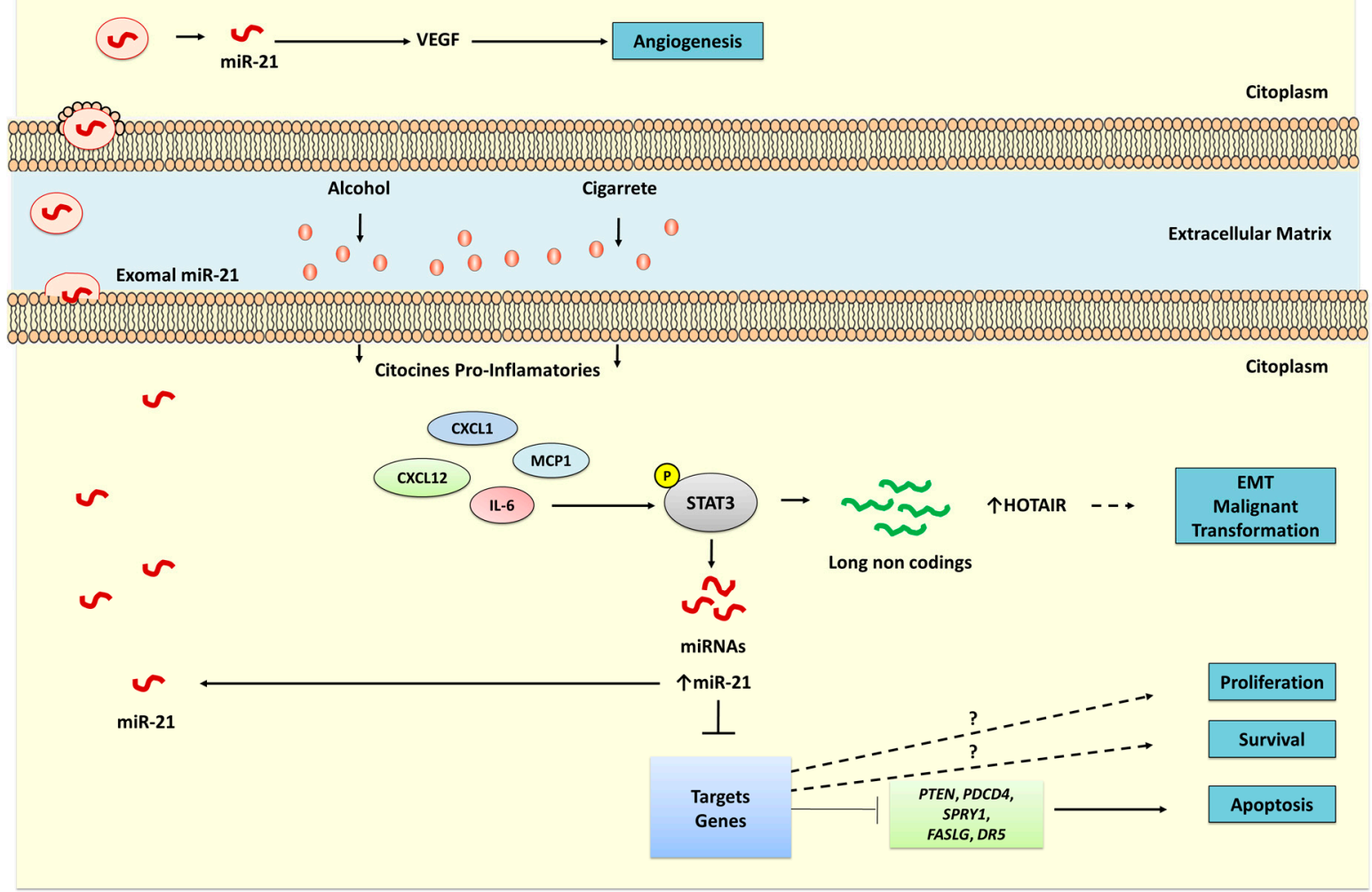

Figure 2. Induction of cellular inflammatory processes by tobacco and alcohol. Tobacco and alcohol induce inflammatory processes primarily through the interleukin 6 (IL-6)/signal transducer and activator of transcription 3 (STAT3) pathway. Phosphorylation of STAT3 by IL-6 governs the expression of miRNAs and long noncoding RNAs (lncRNAs). In aortic artery aneurysms and lung and liver cancers, miR-21 is associated with alterations in the IL-6/STAT3 pathway. Cells chronically exposed to cigarette smoke extract (CSE) show increased expression and secretion of miR-21 in exosomes and greater angiogenesis. CSE also induces the epithelial-mesenchymal transition (EMT) and upregulates the HOX transcript antisense RNA (HOTAIR) lncRNA. This pathway is involved in many processes, thus representing a new approach for identifying therapeutic targets in disorders associated with the use of alcohol and tobacco. miR-21: microRNA-21; VEGF: Vascular endothelial growth factor; MCP1: monocyte chemotactic protein-1; CXCL12: stromal cell-derived factor-; CXCL1: chemokine C-X-C motif ligand 1; IL-6: interleukin-6; STAT3: Signal transducer and activator of transcription 3; PTEN: phosphatase and tensin homolog; PDCD4: programmed cell death 4; SPRY1: sprouty-1; FASLG: TNF superfamily, member 6; DR5: death receptor 5.

\section{Final Considerations}

Despite the various interventions to discourage tobacco and alcohol consumption, they remain the chief risk factors in the development of many diseases worldwide. The discovery of new molecules that are able to assist in the diagnosis and treatment can reduce the incidence and mortality of these diseases. Many studies have demonstrated that in various experimental models-cell lines, animals, tissues, and human fluids-miRNAs are associated with disease, for which alcohol consumption and smoking are potential risk factors. Several advances have been realized using ncRNAs in translational research; however, limited studies have reported the biological processes in which these molecules and mechanisms are involved.

The most prevalent studies are the associations between lung diseases in smokers and miRNAs. Yet, little is known about the influence of alcohol and tobacco on the expression of ncRNA in cardiovascular diseases. 
Exposure to tobacco and alcohol modulates the expression of miRNAs and lncRNAs through the IL-6/STAT3 inflammatory pathway, and this appears to be important for the development of diseases associated with these risk factors. Most work has focused on miRNAs, and little is known about lncRNAs and their function in the development of diseases that are associated with tobacco and alcohol use.

A greater understanding of noncoding RNAs and their respective mechanisms might improve such outcomes and guide the development of novel diagnostic and treatment approaches. However, it is necessary to overcome limitations in integrating and validating the results due to the use of large-scale techniques.

Acknowledgments: We thank The São Paulo Research Foundation-FAPESP (Process \#2014/03021-1) and Coordenação de Aperfeiçoamento de Pessoal de Nível Superior (CAPES) for providing PhD scholarships, for N.S.d.A and N.C.M, respectively.

Author Contributions: N.S.d.A. and R.M.R. constructed the outline of the article; N.S.d.A., N.C.M., and B.d.M.M. wrote the manuscript; N.S.A. and N.C.M. designed the tables and figures; and B.d.M.M. generated the reference list. All authors have reviewed and agreed with the final version of this article.

Conflicts of Interest: The authors declare no conflict of interest.

\section{References}

1. World Health Organization. Global Information System on Alcohol and Health (GISAH). Available online: http://www.who.int/gho/alcohol/en/ (accessed on 20 November 2016).

2. Zhou, Y.; Zheng, J.; Li, S.; Zhou, T.; Zhang, P.; Li, H.B. Alcoholic Beverage Consumption and Chronic Diseases. Int. J. Environ. Res. Public Health 2016, 13, 522. [CrossRef] [PubMed]

3. Leyro, T.M.; Crew, E.E.; Bryson, S.W.; Lembke, A.; Bailey, S.R.; Prochaska, J.J.; Henriksen, L.; Fortmann, S.P.; Killen, J.D.; Killen, D.T.; et al. Retrospective analysis of changing characteristics of treatment-seeking smokers: Implications for further reducing smoking prevalence. BMJ Open 2016, 6, e010960. [CrossRef] [PubMed]

4. Mathers, C.D.; Loncar, D. Projections of global mortality and burden of disease from 2002 to 2030. PLoS Med. 2006, 3, e442. [CrossRef] [PubMed]

5. Parkin, D.M.; Boyd, L.; Walker, L.C. The fraction of cancer attributable to lifestyle and environmental factors in the UK in 2010. Br. J. Cancer 2011, 105 (Suppl. S2), S77-S81. [CrossRef] [PubMed]

6. Alegría-Torres, J.A.; Baccarelli, A.; Bollati, V. Epigenetics and lifestyle. Epigenomics 2011, 3, 267-277. [CrossRef] [PubMed]

7. Liu, Y.; Luo, F.; Xu, Y.; Wang, B.; Zhao, Y.; Xu, W.; Shi, L.; Lu, X.; Liu, Q. Epithelial-mesenchymal transition and cancer stem cells, mediated by a long noncoding RNA, HOTAIR, are involved in cell malignant transformation induced by cigarette smoke extract. Toxicol. Appl. Pharmacol. 2015, 282, 9-19. [CrossRef] [PubMed]

8. Ma, J.; Lin, Y.; Zhan, M.; Mann, D.L.; Stass, S.A.; Jiang, F. Differential miRNA expressions in peripheral blood mononuclear cells for diagnosis of lung cancer. Lab. Investig. 2015, 95, 1197-1206. [CrossRef] [PubMed]

9. Francis, H.; McDaniel, K.; Han, Y.; Liu, X.; Kennedy, L.; Yang, F.; McCarra, J.; Zhou, T.; Glaser, S.; Venter, J.; et al. Regulation of the extrinsic apoptotic pathway by microRNA-21 in alcoholic liver injury. J. Biol. Chem. 2014, 289, 27526-27539. [CrossRef] [PubMed]

10. Gong, X.; Wei, W.; Chen, L.; Xia, Z.; Yu, C. Comprehensive analysis of long noncoding RNA expression profiles in hepatitis B virus-related hepatocellular carcinoma. Oncotarget 2016. [CrossRef] [PubMed]

11. Vucic, E.A.; Thu, K.L.; Pikor, L.A.; Enfield, K.S.; Yee, J.; English, J.C.; MacAulay, C.E.; Lam, S.; Jurisica, I.; Lam, W.L. Smoking status impacts microRNA mediated prognosis and lung adenocarcinoma biology. BMC Cancer 2014, 14, 778. [CrossRef] [PubMed]

12. Geng, Q.; Fan, T.; Zhang, B.; Wang, W.; Xu, Y.; Hu, H. Five microRNAs in plasma as novel biomarkers for screening of early-stage non-small cell lung cancer. Respir. Res. 2014, 15, 149. [CrossRef] [PubMed]

13. Liu, Y.; Luo, F.; Wang, B.; Li, H.; Xu, Y.; Liu, X.; Shi, L.; Lu, X.; Xu, W.; Lu, L.; et al. STAT3-regulated exosomal miR-21 promotes angiogenesis and is involved in neoplastic processes of transformed human bronchial epithelial cells. Cancer Lett. 2016, 370, 125-135. [CrossRef] [PubMed] 
14. Kashi, K.; Henderson, L.; Bonetti, A.; Carninci, P. Discovery and functional analysis of lncRNAs: Methodologies to investigate an uncharacterized transcriptome. Biochim. Biophys. Acta 2016, 1859, 3-15. [CrossRef] [PubMed]

15. Riquelme, I.; Ili, C.; Roa, J.C.; Brebi, P. Long noncoding RNAs in gastric cancer: Mechanisms and potential applications. Oncotarget 2016. [CrossRef]

16. Hafner, M.; Lianoglou, S.; Tuschl, T.; Betel, D. Genome-wide identification of miRNA targets by PAR-CLIP. Methods 2012, 58, 94-105. [CrossRef] [PubMed]

17. Calin, G.A.; Sevignani, C.; Dumitru, C.D.; Hyslop, T.; Noch, E.; Yendamuri, S.; Shimizu, M.; Rattan, S.; Bullrich, F.; Negrini, M.; et al. Human microRNA genes are frequently located at fragile sites and genomic regions involved in cancers. Proc. Natl. Acad. Sci. USA 2004, 101, 2999-3004. [CrossRef] [PubMed]

18. Kunej, T.; Godnic, I.; Horvat, S.; Zorc, M.; Calin, G.A. Cross talk between microRNA and coding cancer genes. Cancer J. 2012, 18, 223-231. [CrossRef] [PubMed]

19. Eiring, A.M.; Harb, J.G.; Neviani, P.; Garton, C.; Oaks, J.J.; Spizzo, R.; Liu, S.; Schwind, S.; Santhanam, R.; Hickey, C.J.; et al. miR-328 functions as an RNA decoy to modulate hnRNP E2 regulation of mRNA translation in leukemic blasts. Cell 2010, 140, 652-665. [CrossRef] [PubMed]

20. Garzon, R.; Marcucci, G.; Croce, C.M. Targeting microRNAs in cancer: Rationale, strategies and challenges. Nat. Rev. Drug Discov. 2010, 9, 775-789. [CrossRef] [PubMed]

21. Fabbri, M.; Paone, A.; Calore, F.; Galli, R.; Gaudio, E.; Santhanam, R.; Lovat, F.; Fadda, P.; Mao, C.; Nuovo, G.J.; et al. MicroRNAs bind to Toll-like receptors to induce prometastatic inflammatory response. Proc. Natl. Acad. Sci. USA 2012, 109, E2110-E2116. [CrossRef] [PubMed]

22. Fabbri, M.; Garzon, R.; Cimmino, A.; Liu, Z.; Zanesi, N.; Callegari, E.; Liu, S.; Alder, H.; Costinean, S.; Fernandez-Cymering, C.; et al. MicroRNA-29 family reverts aberrant methylation in lung cancer by targeting DNA methyltransferases 3A and 3B. Proc. Natl. Acad. Sci. USA 2007, 104, 15805-15810. [CrossRef] [PubMed]

23. Vasudevan, S.; Tong, Y.; Steitz, J.A. Switching from repression to activation: MicroRNAs can up-regulate translation. Science 2007, 318, 1931-1934. [CrossRef] [PubMed]

24. Endzeliņš, E.; Melne, V.; Kalniņa, Z.; Lietuvietis, V.; Riekstiņa, U.; Llorente, A.; Linē, A. Diagnostic, prognostic and predictive value of cell-free miRNAs in prostate cancer: A systematic review. Mol. Cancer 2016, 15, 41. [CrossRef] [PubMed]

25. Shah, M.Y.; Calin, G.A. MicroRNAs as therapeutic targets in human cancers. Wiley Interdiscip. Rev. RNA 2014, 5, 537-548. [CrossRef] [PubMed]

26. Esteller, M. Noncoding RNAs in human disease. Nat. Rev. Genet. 2011, 12, 861-874. [CrossRef] [PubMed]

27. Tuna, M.; Machado, A.S.; Calin, G.A. Genetic and epigenetic alterations of microRNAs and implications for human cancers and other diseases. Genes Chromosomes Cancer 2016, 55, 193-214. [CrossRef] [PubMed]

28. Borchert, G.M.; Lanier, W.; Davidson, B.L. RNA polymerase III transcribes human microRNAs. Nat. Struct. Mol. Biol. 2006, 13, 1097-1101. [CrossRef] [PubMed]

29. Gurtner, A.; Falcone, E.; Garibaldi, F.; Piaggio, G. Dysregulation of microRNA biogenesis in cancer: The impact of mutant p53 on Drosha complex activity. J. Exp. Clin. Cancer Res. 2016, 35, 45. [CrossRef] [PubMed]

30. Meng, F.; Glaser, S.S.; Francis, H.; Yang, F.; Han, Y.; Stokes, A.; Staloch, D.; McCarra, J.; Liu, J.; Venter, J.; et al. Epigenetic regulation of miR-34a expression in alcoholic liver injury. Am. J. Pathol. 2012, 181, 804-817. [CrossRef] [PubMed]

31. Kitagawa, N.; Ojima, H.; Shirakihara, T.; Shimizu, H.; Kokubu, A.; Urushidate, T.; Totoki, Y.; Kosuge, T.; Miyagawa, S.; Shibata, T. Downregulation of the microRNA biogenesis components and its association with poor prognosis in hepatocellular carcinoma. Cancer Sci. 2013, 104, 543-551. [CrossRef] [PubMed]

32. Chu, Y.H.; Hsieh, M.J.; Chiou, H.L.; Liou, Y.S.; Yang, C.C.; Yang, S.F.; Kuo, W.H. MicroRNA gene polymorphisms and environmental factors increase patient susceptibility to hepatocellular carcinoma. PLoS ONE 2014, 9, e89930. [CrossRef] [PubMed]

33. Rupaimoole, R.; Ivan, C.; Yang, D.; Gharpure, K.M.; Wu, S.Y.; Pecot, C.V.; Previs, R.A.; Nagaraja, A.S.; Armaiz-Pena, G.N.; McGuire, M.; et al. Hypoxia-upregulated microRNA-630 targets Dicer, leading to increased tumor progression. Oncogene 2016, 35, 4312-4320. [CrossRef] [PubMed]

34. Gross, T.J.; Powers, L.S.; Boudreau, R.L.; Brink, B.; Reisetter, A.; Goel, K.; Gerke, A.K.; Hassan, I.H.; Monick, M.M. A microRNA processing defect in smokers' macrophages is linked to SUMOylation of the endonuclease DICER. J. Biol. Chem. 2014, 289, 12823-12834. [CrossRef] [PubMed] 
35. Geisler, S.; Coller, J. RNA in unexpected places: Long non-coding RNA functions in diverse cellular contexts. Nat. Rev. Mol. Cell Biol. 2013, 14, 699-712. [CrossRef] [PubMed]

36. Loewer, S.; Cabili, M.N.; Guttman, M.; Loh, Y.H.; Thomas, K.; Park, I.H.; Garber, M.; Curran, M.; Onder, T.; Agarwal, S.; et al. Large intergenic non-coding RNA-RoR modulates reprogramming of human induced pluripotent stem cells. Nat. Genet. 2010, 42, 1113-1117. [CrossRef] [PubMed]

37. Derrien, T.; Johnson, R.; Bussotti, G.; Tanzer, A.; Djebali, S.; Tilgner, H.; Guernec, G.; Martin, D.; Merkel, A.; Knowles, D.G.; et al. The GENCODE v7 catalog of human long noncoding RNAs: Analysis of their gene structure; evolution; and expression. Genome Res. 2012, 22, 1775-1789. [CrossRef] [PubMed]

38. Nakagawa, S.; Kageyama, Y. Nuclear IncRNAs as epigenetic regulators-Beyond skepticism. Biochim. Biophys. Acta 2014, 1839, 215-222. [CrossRef] [PubMed]

39. Fatica, A.; Bozzoni, I. Long non-coding RNAs: New players in cell differentiation and development. Nat. Rev. Genet. 2014, 15, 7-21. [CrossRef] [PubMed]

40. Heward, J.A.; Lindsay, M.A. Long non-coding RNAs in the regulation of the immune response. Trends Immunol. 2014, 35, 408-419. [CrossRef] [PubMed]

41. Wan, P.; Su, W.; Zhuo, Y. The Role of Long Noncoding RNAs in Neurodegenerative Diseases. Mol. Neurobiol. 2016. [CrossRef] [PubMed]

42. Archer, K.; Broskova, Z.; Bayoumi, A.S.; Teoh, J.P.; Davila, A.; Tang, Y.; Su, H.; Kim, I.M. Long Non-Coding RNAs as Master Regulators in Cardiovascular Diseases. Int. J. Mol. Sci. 2015, 16, 23651-23667. [CrossRef] [PubMed]

43. Sun, X.; Wong, D. Long non-coding RNA-mediated regulation of glucose homeostasis and diabetes. Am. J. Cardiovasc. Dis. 2016, 18, 17-25.

44. Thai, P.; Statt, S.; Chen, C.H.; Liang, E.; Campbell, C.; Wu, R. Characterization of a novel long noncoding RNA; SCAL1; induced by cigarette smoke and elevated in lung cancer cell lines. Am. J. Respir. Cell Mol. Biol. 2013, 49, 204-211. [CrossRef] [PubMed]

45. Lai, M.C.; Yang, Z.; Zhou, L.; Zhu, Q.Q.; Xie, H.Y.; Zhang, F.; Wu, L.M.; Chen, L.M.; Zheng, S.S. Long noncoding RNA MALAT-1 overexpression predicts tumor recurrence of hepatocellular carcinoma after liver transplantation. Med. Oncol. 2012, 29, 1810-1816. [CrossRef] [PubMed]

46. Doll, R.; Hill, A.B. Smoking and carcinoma of the lung; preliminary report. Br. Med. J. 1950, 2, 739-748.

47. IARC Working Group on the Evaluation of Carcinogenic Risks to Humans. Personal habits and indoor combustions. Volume 100 E. A review of human carcinogens. IARC Monogr. Eval. Carcinog. Risks Hum. 2012, $100 E, 1-598$.

48. U.S. Department of Health and Human Services. Fifty Years of Change 1964-2014. In The Health Consequences of Smoking: 50 Years of Progress; A Report of the Surgeon General; U.S. Department of Health and Human Services; Centers for Disease Control and Prevention; National Center for Chronic Disease Prevention and Health Promotion; Office on Smoking and Health: Atlanta, GA, USA, 2014; pp. 15-41.

49. Gritz, E.R.; Fingeret, M.C.; Vidrine, D.J.; Lazev, A.B.; Mehta, N.V.; Reece, G.P. Successes and failures of the teachable moment: Smoking cessation in cancer patients. Cancer 2006, 106, 17-27. [CrossRef] [PubMed]

50. Benjamin, R.M. Exposure to tobacco smoke causes immediate damage: A report of the Surgeon General. Public Health Rep. 2011, 126, 158-159. [PubMed]

51. Wang, L.; Li, X.; Zhou, Y.; Shi, H.; Xu, C.; He, H.; Wang, S.; Xiong, X.; Zhang, Y.; Du, Z.; et al. Downregulation of miR-133 via MAPK/ERK signaling pathway involved in nicotine-induced cardiomyocyte apoptosis. Naunyn-Schmiedeberg Arch. Pharmacol. 2014, 387, 197-206. [CrossRef] [PubMed]

52. Maegdefessel, L.; Azuma, J.; Toh, R.; Deng, A.; Merk, D.R.; Raiesdana, A.; Leeper, N.J.; Raaz, U.; Schoelmerich, A.M.; McConnell, M.V.; et al. MicroRNA-21 blocks abdominal aortic aneurysm development and nicotine-augmented expansion. Sci. Transl. Med. 2012, 4, 122ra22. [CrossRef] [PubMed]

53. Wang, G.; Wang, R.; Strulovici-Barel, Y.; Salit, J.; Staudt, M.R.; Ahmed, J.; Tilley, A.E.; Yee-Levin, J.; Hollmann, C.; Harvey, B.G.; et al. Persistence of smoking-induced dysregulation of miRNA expression in the small airway epithelium despite smoking cessation. PLoS ONE 2015, 10, e0120824. [CrossRef] [PubMed]

54. Roth, C.; Stückrath, I.; Pantel, K.; Izbicki, J.R.; Tachezy, M.; Schwarzenbach, H. Low levels of cell-free circulating miR-361-3p and miR-625* as blood-based markers for discriminating malignant from benign lung tumors. PLoS ONE 2012, 7, e38248. [CrossRef] [PubMed]

55. American Cancer Society (ACS). Cancer Facts \& Figures 2012. J. Consum. Health Internet 2012, 16, 366-367. 
56. Su, M.W.; Yu, S.L.; Lin, W.C.; Tsai, C.H.; Chen, P.H.; Lee, Y.L. Smoking-related microRNAs and mRNAs in human peripheral blood mononuclear cells. Toxicol. Appl. Pharmacol. 2016, 305, 169-175. [CrossRef] [PubMed]

57. Izzotti, A.; Balansky, R.; Ganchev, G.; Iltcheva, M.; Longobardi, M.; Pulliero, A.; Geretto, M.; Micale, R.T.; La Maestra, S.; Miller, M.S.; et al. Blood and lung microRNAs as biomarkers of pulmonary tumorigenesis in cigarette smoke-exposed mice. Oncotarget 2016. [CrossRef] [PubMed]

58. Huang, J.; Wu, J.; Li, Y.; Li, X.; Yang, T.; Yang, Q.; Jiang, Y. Deregulation of serum microRNA expression is associated with cigarette smoking and lung cancer. BioMed Res. Int. 2014, 2014, 364316. [CrossRef] [PubMed]

59. Zhang, Y.K.; Zhu, W.Y.; He, J.Y.; Chen, D.D.; Huang, Y.Y.; Le, H.B.; Liu, X.G. miRNAs expression profiling to distinguish lung squamous-cell carcinoma from adenocarcinoma subtypes. J. Cancer Res. Clin. Oncol. 2012, 138, 1641-1650. [CrossRef] [PubMed]

60. Jang, J.S.; Jeon, H.S.; Sun, Z.; Aubry, M.C.; Tang, H.; Park, C.H.; Rakhshan, F.; Schultz, D.A.; Kolbert, C.P.; Lupu, R.; et al. Increased miR-708 expression in NSCLC and its association with poor survival in lung adenocarcinoma from never smokers. Clin. Cancer Res. 2012, 18, 3658-3667. [CrossRef] [PubMed]

61. Kim, S.C.; Jung, Y.; Park, J.; Cho, S.; Seo, C.; Kim, J.; Kim, P.; Park, J.; Seo, J.; Kim, J.; et al. A high-dimensional; deep-sequencing study of lung adenocarcinoma in female never-smokers. PLoS ONE 2013, 8, e55596. [CrossRef] [PubMed]

62. Xu, F.; Zhang, H.; Su, Y.; Kong, J.; Yu, H.; Qian, B. Up-regulation of microRNA-183-3p is a potent prognostic marker for lung adenocarcinoma of female non-smokers. Clin. Transl. Oncol. 2014, 16, 980-985. [CrossRef] [PubMed]

63. Shen, J.; Liu, Z.; Todd, N.W.; Zhang, H.; Liao, J.; Yu, L.; Guarnera, M.A.; Li, R.; Cai, L.; Zhan, M.; et al. Diagnosis of lung cancer in individuals with solitary pulmonary nodules by plasma microRNA biomarkers. BMC Cancer 2011, 11, 374. [CrossRef] [PubMed]

64. Shen, J.; Liao, J.; Guarnera, M.A.; Fang, H.; Cai, L.; Stass, S.A.; Jiang, F. Analysis of microRNAs in sputum to improve computed tomography for lung cancer diagnosis. J. Thorac. Oncol. 2014, 9, 33-40. [CrossRef] [PubMed]

65. Sozzi, G.; Boeri, M.; Rossi, M.; Verri, C.; Suatoni, P.; Bravi, F.; Roz, L.; Conte, D.; Grassi, M.; Sverzellati, N.; et al. Clinical utility of a plasma-based miRNA signature classifier within computed tomography lung cancer screening: A correlative MILD trial study. J. Clin. Oncol. 2014, 32, 768-773. [CrossRef] [PubMed]

66. Wali, R.K.; Hensing, T.A.; Ray, D.W.; Dela Cruz, M.; Tiwari, A.K.; Radosevich, A.; Jepeal, L.; Fernando, H.C.; Litle, V.R.; Charlot, M.; et al. Buccal microRNA dysregulation in lung field carcinogenesis: Gender-specific implications. Int. J. Oncol. 2014, 45, 1209-1215. [CrossRef] [PubMed]

67. Perdomo, C.; Campbell, J.D.; Gerrein, J.; Tellez, C.S.; Garrison, C.B.; Walser, T.C.; Drizik, E.; Si, H.; Gower, A.C.; Vick, J.; et al. MicroRNA 4423 is a primate-specific regulator of airway epithelial cell differentiation and lung carcinogenesis. Proc. Natl. Acad. Sci. USA 2013, 110, 18946-18951. [CrossRef] [PubMed]

68. Balansky, R.; Izzotti, A.; D’Agostini, F.; Longobardi, M.; Micale, R.T.; La Maestra, S.; Camoirano, A.; Ganchev, G.; Iltcheva, M.; Steele, V.E.; et al. Assay of lapatinib in murine models of cigarette smoke carcinogenesis. Carcinogenesis 2014, 35, 2300-2307. [CrossRef] [PubMed]

69. Xi, S.; Inchauste, S.; Guo, H.; Shan, J.; Xiao, Z.; Xu, H.; Miettenen, M.; Zhang, M.R.; Hong, J.A.; Raiji, M.T.; et al. Cigarette smoke mediates epigenetic repression of miR-217 during esophageal adenocarcinogenesis. Oncogene 2015, 34, 5548-5559. [CrossRef] [PubMed]

70. Stánitz, E.; Juhász, K.; Tóth, C.; Gombos, K.; Natali, P.G.; Ember, I. Evaluation of microRNA expression pattern of gastric adenocarcinoma associated with socioeconomic, environmental and lifestyle factors in northwestern Hungary. Anticancer Res. 2013, 33, 3195-3200. [PubMed]

71. Kolokythas, A.; Zhou, Y.; Schwartz, J.L.; Adami, G.R. Similar Squamous Cell Carcinoma Epithelium microRNA Expression in Never Smokers and Ever Smokers. PLoS ONE 2015, 10, e0141695. [CrossRef] [PubMed]

72. O’Leary, L.; Sevinç, K.; Papazoglou, I.M.; Tildy, B.; Detillieux, K.; Halayko, A.J.; Chung, K.F.; Perry, M.M. Airway smooth muscle inflammation is regulated by microRNA-145 in COPD. FEBS Lett. 2016, 590, 1324-1334. [CrossRef] [PubMed]

73. Friedlander, A.L.; Lynch, D.; Dyar, L.A.; Bowler, R.P. Phenotypes of chronic obstructive pulmonary disease. COPD 2007, 4, 355-384. [CrossRef] [PubMed] 
74. Campbell, J.D.; McDonough, J.E.; Zeskind, J.E.; Hackett, T.L.; Pechkovsky, D.V.; Brandsma, C.A.; Suzuki, M.; Gosselink, J.V.; Liu, G.; Alekseyev, Y.O.; et al. A gene expression signature of emphysema-related lung destruction and its reversal by the tripeptide GHK. Genome Med. 2012, 4, 67. [CrossRef] [PubMed]

75. Van Pottelberge, G.R.; Mestdagh, P.; Bracke, K.R.; Thas, O.; van Durme, Y.M.; Joos, G.F.; Vandesompele, J.; Brusselle, G.G. MicroRNA expression in induced sputum of smokers and patients with chronic obstructive pulmonary disease. Am. J. Respir. Crit. Care Med. 2011, 183, 898-906. [CrossRef] [PubMed]

76. Oldenburger, A.; van Basten, B.; Kooistra, W.; Meurs, H.; Maarsingh, H.; Krenning, G.; Timens, W.; Schmidt, M. Interaction between Epac1 and miRNA-7 in airway smooth muscle cells. Naunyn-Schmiedeberg Arch. Pharmacol. 2014, 387, 795-797. [CrossRef] [PubMed]

77. Ezzie, M.E.; Crawford, M.; Cho, J.H.; Orellana, R.; Zhang, S.; Gelinas, R.; Batte, K.; Yu, L.; Nuovo, G.; Galas, D.; et al. Gene expression networks in COPD: MicroRNA and mRNA regulation. Thorax 2012, 67, 122-131. [CrossRef] [PubMed]

78. Chatila, W.M.; Criner, G.J.; Hancock, W.W.; Akimova, T.; Moldover, B.; Chang, J.K.; Cornwell, W.; Santerre, M.; Rogers, T.J. Blunted expression of miR-199a-5p in regulatory T cells of patients with chronic obstructive pulmonary disease compared to unaffected smokers. Clin. Exp. Immunol. 2014, 177, 341-352. [CrossRef] [PubMed]

79. Graff, J.W.; Powers, L.S.; Dickson, A.M.; Kim, J.; Reisetter, A.C.; Hassan, I.H.; Kremens, K.; Gross, T.J.; Wilson, M.E.; Monick, M.M. Cigarette smoking decreases global microRNA expression in human alveolar macrophages. PLoS ONE 2012, 7, e44066. [CrossRef] [PubMed]

80. Sheridan, J.A.; Zago, M.; Nair, P.; Li, P.Z.; Bourbeau, J.; Tan, W.C.; Hamid, Q.; Eidelman, D.H.; Benedetti, A.L.; Baglole, C.J. Decreased expression of the NF-кB family member RelB in lung fibroblasts from smokers with and without COPD potentiates cigarette smoke-induced COX-2 expression. Respir. Res. 2015, 16, 54. [CrossRef] [PubMed]

81. Wang, R.; Li, M.; Zhou, S.; Zeng, D.; Xu, X.; Xu, R.; Sun, G. Effect of a single nucleotide polymorphism in $\mathrm{miR}-146 \mathrm{a}$ on COX-2 protein expression and lung function in smokers with chronic obstructive pulmonary disease. Int. J. Chronic Obstr. Pulm. Dis. 2015, 10, 463-473.

82. Soeda, S.; Ohyashiki, J.H.; Ohtsuki, K.; Umezu, T.; Setoguchi, Y.; Ohyashiki, K. Clinical relevance of plasma miR-106b levels in patients with chronic obstructive pulmonary disease. Int. J. Mol. Med. 2013, 31, 533-539. [CrossRef] [PubMed]

83. Shi, L.; Xin, Q.; Chai, R.; Liu, L.; Ma, Z. Ectopic expressed miR-203 contributes to chronic obstructive pulmonary disease via targeting TAK1 and PIK3CA. Int. J. Clin. Exp. Pathol. 2015, 8, 10662-10670. [PubMed]

84. World Health Organization. Cardiovascular Disease. Available online: http://www.who.int/cardiovascular _diseases/global-hearts/Global_hearts_initiative/en/ (accessed on 20 November 2016).

85. Lachenmeier, D.W.; Przybylski, M.C.; Rehm, J. Comparative risk assessment of carcinogens in alcoholic beverages using the margin of exposure approach. Int. J. Cancer 2012, 131, E995-E1003. [CrossRef] [PubMed]

86. Torre, L.A.; Bray, F.; Siegel, R.L.; Ferlay, J.; Lortet-Tieulent, J.; Jemal, A. Global cancer statistics, 2012. CA Cancer J. Clin. 2015, 65, 87-108. [CrossRef] [PubMed]

87. Gao, J.; Xie, L.; Yang, W.S.; Zhang, W.; Gao, S.; Wang, J.; Xiang, Y.B. Risk factors of hepatocellular carcinoma-current status and perspectives. Asian Pac. J. Cancer Prev. 2012, 13, 743-752. [CrossRef] [PubMed]

88. McGlynn, K.A.; London, W.T. The global epidemiology of hepatocellular carcinoma: Present and future. Clin. Liver Dis. 2011, 15, 223-243. [CrossRef] [PubMed]

89. Persson, E.C.; Schwartz, L.M.; Park, Y.; Trabert, B.; Hollenbeck, A.R.; Graubard, B.I.; Freedman, N.D.; McGlynn, K.A. Alcohol consumption, folate intake, hepatocellular carcinoma, and liver disease mortality. Cancer Epidemiol. Biomark. Prev. 2013, 22, 415-421. [CrossRef] [PubMed]

90. Gong, X.L.; Qin, S.K. Progress in systemic therapy of advanced hepatocellular carcinoma. World J. Gastroenterol. 2016, 22, 6582-6594. [CrossRef] [PubMed]

91. Mizuguchi, Y.; Isse, K.; Specht, S.; Lunz, J.G.; Corbitt, N.; Takizawa, T.; Demetris, A.J. Small proline rich protein 2a in benign and malignant liver disease. Hepatology 2014, 59, 1130-1143. [CrossRef] [PubMed]

92. Hou, W.; Bukong, T.N.; Kodys, K.; Szabo, G. Alcohol facilitates HCV RNA replication via up-regulation of miR-122 expression and inhibition of cyclin G1 inhuman hepatoma cells. Alcohol. Clin. Exp. Res. 2013, 37, 599-608. [CrossRef] [PubMed] 
93. Bala, S.; Petrasek, J.; Mundkur, S.; Catalano, D.; Levin, I.; Ward, J.; Alao, H.; Kodys, K.; Szabo, G. Circulating microRNAs in exosomes indicate hepatocyte injury and inflammation in alcoholic; drug-induced; and inflammatory liver diseases. Hepatology 2012, 56, 1946-1957. [CrossRef] [PubMed]

94. Miranda, R.C.; Pietrzykowski, A.Z.; Tang, Y.; Sathyan, P.; Mayfield, D.; Keshavarzian, A.; Sampson, W.; Hereld, D. MicroRNAs: Master regulators of ethanol abuse and toxicity? Alcohol. Clin. Exp. Res. 2010, 34, 575-587. [CrossRef] [PubMed]

95. Yu, G.; Xiao, Q.; Ma, X.P.; Chen, X.; Shi, Z.; Zhang, L.Y.; Chen, H.; Zhang, P.; Ding, D.L.; Huang, H.X.; et al. miR-492G >C polymorphism (rs2289030) is associated with overall survival of hepatocellular carcinoma patients. Tumor Biol. 2016, 37, 8961-8972. [CrossRef] [PubMed]

96. Saad, M.A.; Kuo, S.Z.; Rahimy, E.; Zou, A.E.; Korrapati, A.; Rahimy, M.; Kim, E.; Zheng, H.; Yu, M.A.; Wang-Rodriguez, J.; et al. Alcohol-dysregulated miR-30a and miR-934 in head and neck squamous cell carcinoma. Mol. Cancer 2015, 14, 181. [CrossRef] [PubMed]

97. Manikandan, M.; Deva Magendhra Rao, A.K.; Arunkumar, G.; Rajkumar, K.S.; Rajaraman, R.; Munirajan, A.K. Down Regulation of miR-34a and miR-143 May Indirectly Inhibit p53 in Oral Squamous Cell Carcinoma: A Pilot Study. Asian Pac. J. Cancer Prev. 2015, 16, 7619-7625. [CrossRef] [PubMed]

98. Hu, Y.; Liu, H. MicroRNA-10a-5p and microRNA-34c-5p in laryngeal epithelial premalignant lesions: Differential expression and clinicopathological correlation. Eur. Arch. Otorhinolaryngol. 2015, 272, 391-399. [CrossRef] [PubMed]

99. O'Shea, R.S.; Dasarathy, S.; McCullough, A.J. Alcoholic liver disease. Am. J. Gastroenterol. 2010, 105, 14-32. [CrossRef] [PubMed]

100. Liu, Y.; Chen, S.H.; Jin, X.; Li, Y.M. Analysis of differentially expressed genes and microRNAs in alcoholic liver disease. Int. J. Mol. Med. 2013, 31, 547-554. [CrossRef] [PubMed]

101. Saha, B.; Momen-Heravi, F.; Kodys, K.; Szabo, G. MicroRNA Cargo of Extracellular Vesicles from Alcohol-exposed Monocytes Signals Naive Monocytes to Differentiate into M2 Macrophages. J. Biol. Chem. 2016, 291, 149-159. [CrossRef] [PubMed]

102. Momen-Heravi, F.; Saha, B.; Kodys, K.; Catalano, D.; Satishchandran, A.; Szabo, G. Increased number of circulating exosomes and their microRNA cargos are potential novel biomarkers in alcoholic hepatitis. J. Transl. Med. 2015, 13, 261. [CrossRef] [PubMed]

103. Chen, Y.P.; Jin, X.; Kong, M.; Li, Y.M. Pattern of microRNA expression associated with different stages of alcoholic liver disease in rat models. Mol. Med. Rep. 2014, 10, 1195-1204. [CrossRef] [PubMed]

104. Szabo, G.; Mandrekar, P.; Petrasek, J.; Catalano, D. The unfolding web of innate immune dysregulation in alcoholic liver injury. Alcohol. Clin. Exp. Res. 2011, 35, 782-786. [CrossRef] [PubMed]

105. Yin, H.; Liang, X.; Jogasuria, A.; Davidson, N.O.; You, M. miR-217 regulates ethanol-induced hepatic inflammation by disrupting sirtuin 1-lipin-1 signaling. Am. J. Pathol. 2015, 185, 1286-1296. [CrossRef] [PubMed]

106. Tang, Y.; Zhang, L.; Forsyth, C.B.; Shaikh, M.; Song, S.; Keshavarzian, A. The Role of miR-212 and iNOS in Alcohol-Induced Intestinal Barrier Dysfunction and Steatohepatitis. Alcohol. Clin. Exp. Res. 2015, 39, 1632-1641. [CrossRef] [PubMed]

107. Cazzoli, R.; Buttitta, F.; Di Nicola, M.; Malatesta, S.; Marchetti, A.; Rom, W.N.; Pass, H.I. MicroRNAs derived from circulating exosomes as noninvasive biomarkers for screening and diagnosing lung cancer. J. Thorac. Oncol. 2013, 8, 1156-1162. [CrossRef] [PubMed]

108. Sun, Y.; Su, B.; Zhang, P.; Xie, H.; Zheng, H.; Xu, Y.; Du, Q.; Zeng, H.; Zhou, X.; Chen, C.; et al. Expression of miR-150 and miR-3940-5p is reduced in non-small cell lung carcinoma and correlates with clinicopathological features. Oncol. Rep. 2013, 29, 704-712. [PubMed]

109. Mascaux, C.; Feser, W.J.; Lewis, M.T.; Barón, A.E.; Coldren, C.D.; Merrick, D.T.; Kennedy, T.C.; Eckelberger, J.I.; Rozeboom, L.M.; Franklin, W.A.; et al. Endobronchial miRNAs as biomarkers in lung cancer chemoprevention. Cancer Prev. Res. 2013, 6, 100-108. [CrossRef] [PubMed]

110. Lu, L.; Luo, F.; Liu, Y.; Liu, X.; Shi, L.; Lu, X.; Liu, Q. Posttranscriptional silencing of the lncRNA MALAT1 by miR-217 inhibits the epithelial-mesenchymal transition via enhancer of zeste homolog 2 in the malignant transformation of HBE cells induced by cigarette smoke extract. Toxicol. Appl. Pharmacol. 2015, 289, 276-285. [CrossRef] [PubMed] 
111. Wu, Y.; Liu, X.; Zhou, Q.; Huang, C.; Meng, X.; Xu, F.; Li, J. Silent information regulator 1 (SIRT1) ameliorates liver fibrosis via promoting activated stellate cell apoptosis and reversion. Toxicol. Appl. Pharmacol. 2015, 289, 163-176. [CrossRef] [PubMed]

112. Yin, H.; Hu, M.; Liang, X.; Ajmo, J.M.; Li, X.; Bataller, R.; Odena, G.; Stevens, S.M.; You, M. Deletion of SIRT1 from hepatocytes in mice disrupts lipin-1 signaling and aggravates alcoholic fatty liver. Gastroenterology 2014, 146, 801-811. [CrossRef] [PubMed]

113. Gong, W.J.; Yin, J.Y.; Li, X.P.; Fang, C.; Xiao, D.; Zhang, W.; Zhou, H.H.; Li, X.; Liu, Z.Q. Association of well-characterized lung cancer lncRNA polymorphisms with lung cancer susceptibility and platinum-based chemotherapy response. Tumor Biol. 2016, 37, 8349-8358. [CrossRef] [PubMed]

114. ENCODE Project Consortium. An integrated encyclopedia of DNA elements in the human genome. Nature 2012, 489, 57-74.

115. Li, X.; Zhang, Y.; Zhang, H.; Liu, X.; Gong, T.; Li, M.; Sun, L.; Ji, G.; Shi, Y.; Han, Z.; et al. miRNA-223 promotes gastric cancer invasion and metastasis by targeting tumor suppressor EPB41L3. Mol. Cancer Res. 2011, 9, 824-833. [CrossRef] [PubMed]

116. Fang, L.; Du, W.W.; Yang, W.; Rutnam, Z.J.; Peng, C.; Li, H.; O’Malley, Y.Q.; Askeland, R.W.; Sugg, S.; Liu, M.; et al. miR-93 enhances angiogenesis and metastasis by targeting LATS2. Cell Cycle 2012, 11, 4352-4365. [CrossRef] [PubMed]

117. Malzkorn, B.; Wolter, M.; Liesenberg, F.; Grzendowski, M.; Stühler, K.; Meyer, H.E.; Reifenberger, G. Identification and functional characterization of microRNAs involved in the malignant progression of gliomas. Brain Pathol. 2010, 20, 539-550. [CrossRef] [PubMed]

118. Nakada, C.; Tsukamoto, Y.; Matsuura, K.; Nguyen, T.L.; Hijiya, N.; Uchida, T.; Sato, F.; Mimata, H.; Seto, M.; Moriyama, M. Overexpression of miR-210, a downstream target of HIF1 $\alpha$, causes centrosome amplification in renal carcinoma cells. J. Pathol. 2011, 224, 280-288. [CrossRef] [PubMed]

119. Bansal, A.; Lee, I.H.; Hong, X.; Anand, V.; Mathur, S.C.; Gaddam, S.; Rastogi, A.; Wani, S.B.; Gupta, N.; Visvanathan, M.; et al. Feasibility of microRNAs as biomarkers for Barrett's esophagus progression: A pilot cross-sectional, phase 2 biomarker study. Am. J. Gastroenterol. 2011, 106, 1055-1063. [CrossRef] [PubMed]

120. Huang, X.; Ding, L.; Bennewith, K.L.; Tong, R.T.; Welford, S.M.; Ang, K.K.; Story, M.; Le, Q.T.; Giaccia, A.J. Hypoxia-inducible miR-210 regulates normoxic gene expression involved in tumor initiation. Mol. Cell 2009, 35, 856-867. [CrossRef] [PubMed] 